\title{
Phytotoxicity of Sodium Fluoride and Uptake of Fluoride to Willow Trees
}

\author{
Clausen, Lauge Peter Westergaard; Gosewinkel Karlson, Ulrich; Trapp, Stefan
}

Publication date:

2014

Document Version

Publisher's PDF, also known as Version of record

Link back to DTU Orbit

Citation (APA):

Clausen, L. P. W., Gosewinkel Karlson, U., \& Trapp, S. (2014). Phytotoxicity of Sodium Fluoride and Uptake of Fluoride to Willow Trees. Poster session presented at 11th International conference of Phytotechnologies, Heraklion, Greece.

\section{General rights}

Copyright and moral rights for the publications made accessible in the public portal are retained by the authors and/or other copyright owners and it is a condition of accessing publications that users recognise and abide by the legal requirements associated with these rights.

- Users may download and print one copy of any publication from the public portal for the purpose of private study or research.

- You may not further distribute the material or use it for any profit-making activity or commercial gain

- You may freely distribute the URL identifying the publication in the public portal

If you believe that this document breaches copyright please contact us providing details, and we will remove access to the work immediately and investigate your claim 


\title{
Phytotoxicity of Sodium Fluoride and Uptake of Fluoride to Willow Trees
}

\author{
Lauge Peter Westergaard Clausen ${ }^{*}$, Ulrich Gosewinkel Karlson ${ }^{2}$ and Stefan Trapp ${ }^{1}$ \\ ${ }^{1}$ Department of Environmental Engineering, Technical University of Denmark \\ ${ }^{2}$ Department of Environmental Science, Aarhus University \\ *Email: Ipwc@env.dtu.dk
}

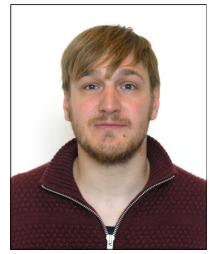

\section{Intro and scope}

Fluoride $(F)$ is present in pristine air, soil and water. As exposure to $F$ through food and beverages is unavoidable, the effects of $F$ on human and mammalian health have been intensely investigated. Due to continued use of super phosphate fertilizers, $\mathrm{F}$ accumulates in agricultural soils. However, little is known about the phytotoxicity of sodium fluoride $(\mathrm{NaF})$ and the uptake of $\mathrm{F}$ when exposed through roots.

The aim of this study is to:

1) Assess the phytotoxicity of $\mathrm{NaF}$ to willows when taken up through the roots

2) Determine the uptake of $F$ to willows when taken up through roots

3) Describe the uptake of $F$ to willows with a non-linear mass balance model

\section{Phytotoxicity results}

- Toxic effects observed within $48 \mathrm{~h}$ for conc. $>100$ $\mathrm{mg} \mathrm{F} \mathrm{L}^{-1}$

- Clear dose-response relationship

- No statistically significant difference between toxicity of $50 \mathrm{mg} \mathrm{F} \mathrm{L}^{-1}$ and $100 \mathrm{mg} \mathrm{F} \mathrm{L}^{-1}$

- Wilting of the trees exposed to $400 \mathrm{mg} \mathrm{F} \mathrm{L}^{-1}$

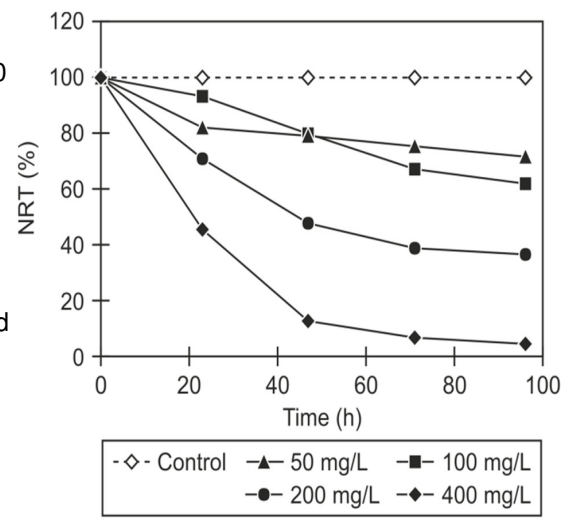

\section{Model parameterization}

- Maximal enzymatic removal rate, $\mathrm{v}_{\max }: 9 \mathrm{~g} \mathrm{~F} \mathrm{~kg}^{-1} \mathrm{~d}^{-1}$

- Breakthrough point (BTP): $210 \mathrm{mg} \mathrm{F} \mathrm{L}^{-1}$ - On a molar basis the same as obtained by Trapp et al. (2008)* for chloride (Cl)

- Uptake slope approx. 1 for C > BTP - unhindered transport with water

\begin{tabular}{|c|c|c|c|c|c|}
\hline Parameter & Value & \multicolumn{2}{|c|}{ Unit } & \multicolumn{2}{|c|}{ Origin } \\
\hline Conc. In solution, $\mathrm{C}_{\mathrm{w}}$ & $0-400$ & \multicolumn{2}{|c|}{$\mathrm{mg} \mathrm{L}^{-1}$} & \multicolumn{2}{|c|}{ Measured } \\
\hline Root mass, $m_{R}$ & 0.001 & \multicolumn{2}{|l|}{$\mathrm{Kg}$} & \multicolumn{2}{|c|}{ Estimated } \\
\hline Transpiration stream, Q & 0.04 & \multicolumn{2}{|l|}{$L d^{-1}$} & \multicolumn{2}{|c|}{ Measured ave. } \\
\hline Half-saturation constant, $\mathrm{K}_{M}$ & 2 & \multicolumn{2}{|l|}{$\mathrm{g} \mathrm{L}^{-1}$} & \multicolumn{2}{|r|}{ Fitted } \\
\hline Max. Enzymatic removal rate, $v_{\max }$ & 8.992 & \multicolumn{2}{|c|}{$\mathrm{g} \mathrm{kg}^{-1} \mathrm{~d}^{-1}$} & \multicolumn{2}{|r|}{ Fitted } \\
\hline Root growth rate, $k_{R}$ & 0 & \multicolumn{2}{|l|}{$d^{-1}$} & \multicolumn{2}{|c|}{ Estimated } \\
\hline & Equation & Valid conc. & $\mathbf{R}^{2}$ & $\mathbf{n}$ & $\mathbf{P}$ \\
\hline Regression 1 & $y=0.128 x-5.186$ & $c<209.5$ & 0.764 & 16 & $<<0.001$ \\
\hline Regression 2 & $y=1.005 x-210.5$ & $C>209.5$ & 0.790 & 8 & $<0.005$ \\
\hline
\end{tabular}

* Trapp S, Feificova D, Rasmussen N F, Bauer-Gottwein P, 2008, Plant uptake of NaCl in relation to enzyme kinetics and toxic effects, Environ. Exp. Bot, $64,1-7$

\section{Experimental setup - the willow tree tox test}

- $40 \mathrm{~cm}$ willow sticks (Salix viminalis) were pre-grown and transferred to Erlenmeyer flasks

- Trees were exposed to solutions of various $\mathrm{NaF}$ concentrations

- Test duration: $96 \mathrm{~h}$

- Normalized Relative Transpiration (NRT) used as test parameter:

$$
\begin{aligned}
& N R T(C, t)(\%)=\frac{\frac{1}{n} \sum_{i=1}^{n} T_{i}(C, t) / T_{i}(C, 0)}{\frac{1}{m} \sum_{j=1}^{m} T_{j}(0, t) / T_{j}(0,0)} \times 100
\end{aligned}
$$

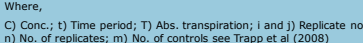

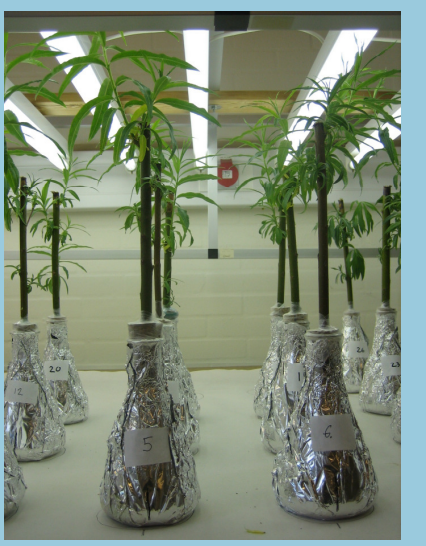

\section{Model description and output}

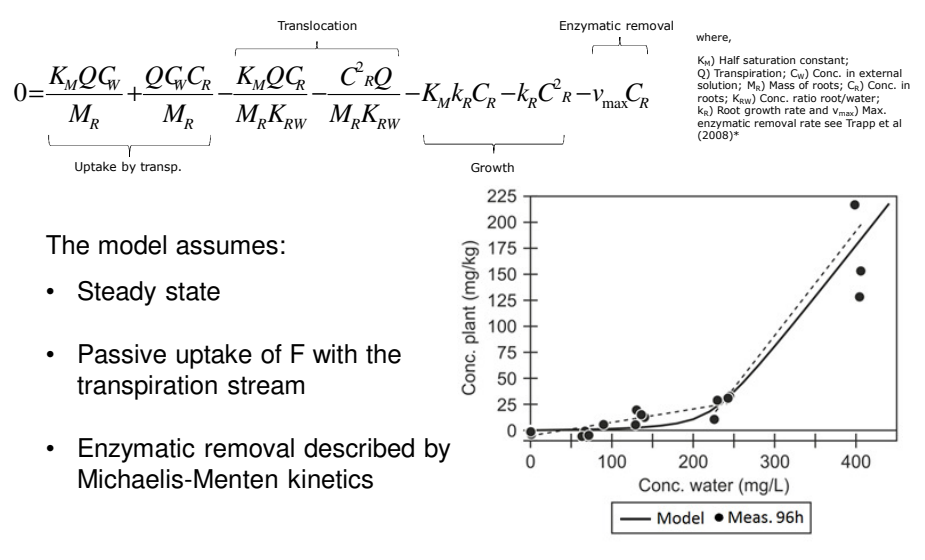

\section{Conclusions}

- $\mathrm{NaF}$ is phytotoxic at levels of $\mathrm{EC}_{10}: 38.0 \pm 34.2 ; \mathrm{EC}_{20}: 59.6 \pm 40.7$ and $\mathrm{EC}_{50}: 128 \pm 51$ (values in $\mathrm{mg} \mathrm{F} \mathrm{L}^{-1} \pm 95 \%$ confidence interval)

- Uptake of F can be described by a non-linear mass balance model assuming enzymatic removal

- At external concentrations above $210 \mathrm{mg} \mathrm{F} \mathrm{L}^{-1}$ the willows can no longer pump out $F$ from the plant cells and start to accumulate $F$

- Enzymatic removal of $\mathrm{F}$ and $\mathrm{Cl}$ from plant cells is likely to be managed by the same "pump"-system

For more details, see: Lauge PW Clausen, Ulrich G Karlson and Stefan Trapp, 2014, Phytotoxicity of Sodium Fluoride and Uptake of Fluoride to Willow Trees, International Journal of Phytoremediation (In press) 